\title{
Az USA gazdaságpolitikai bizonytalanságának batása a geopolitikai kockázatra. A BRIC-gazdaságok által alátámasztott bizonyitékok
}

\begin{abstract}
ÖsszeFoglaló: Ez a cikk az USA gazdaságpolitikai bizonytalansága és a BRIC-országok geopolitikai kockázatának kapcsolatát becsüli meg. Az amerikai gazdaságpolitikai bizonytalanság és a BRIC-országok geopolitikai kockázata közötti nemlineáris és aszimmetrikus összefüggés feltételezése miatt nemparaméteres becslési technikát alkalmazva az empirikus elemzéshez a Quantile on Quantile megközelitést alkalmaztuk. Az empirikus eredményekbőll kiderült, hogy az Egyesült Államok gazdaságpolitikai bizonytalansága és a BRIC-gazdaságok geopolitikai kockázata közötti kapcsolat heterogén jellegú. Megjegyezzük, hogy az USA gazdaságpolitikai bizonytalansága negatívan kapcsolódik a kínai és az orosz gazdaság geopolitikai kockázatához. Az indiai és a brazil gazdaság számára azonban az USA gazdaságpolitikai bizonytalansága pozitív kapcsolatban áll a geopolitikai kockázattal. A tanulmány eredményei hasznosak lehetnek a befektető́k és a pénzügyi piac szereplói számára a befektetési döntések meghozatalában. Ez a törvényalkotóknak és a döntéshozóknak is hasznos lesz olyan politikák kidolgozásában, amelyek gazdaságukat elszigetelhetik külpolitikai kockázatoktól.
\end{abstract}

KuLcsszavak: gazdaságpolitikai bizonytalanság, geopolitikai kockázat, kvantilis/kvantilis megközelítés, BRIC-gazdaságok JEL-Kódok: C22, E32, F51

DOl: https://doi.org/10.35551/PSZ_2020_4_3

Manapság a világ komoly politikai és gazdasági zürzavarral néz szembe. Az olyan események, mint a közel-keleti szövetségek változása, Kína terjeszkedése, az Európai Uniót érő sokk, mint például a Brexit, Trump közigazgatási rendszere az USA-ban és a világ különböző részein, példá-

Levelezési e-cim: arif.i@iuk.edu.pk amna.sohail@iqra.edu.pk m.shahbaz@montpellier-bs.com ul Szíriában, Ukrajnában stb., a kialakult katonai zürzavar a társadalmi és politikai zavargások kockázatának tetőzéséhez vezettek a világban. Ezek a politikai és társadalmi bizonytalanságok kockázatot jelentenek az általánosan geopolitikai kockázatnak tekintett gazdaságra. A geopolitikai kockázat világszerte egyre nagyobb aggodalomra ad okot az üzleti és pénzügyi piacok számára. A PricewaterhouseCoopers (PwC) által készített globális befektetői felmérés (2018) 
szerint a vezérigazgatók 40 százaléka és a befektetési szakemberek 39 százaléka tartotta a geopolitikai kockázatot az egyik legnagyobb fenyegetésnek a vállalkozások és befektetések növekedésére nézve.

A geopolitikai kockázatok kulcsszerepet játszanak a piaci szereplők, a vállalkozók és a jegybanki tisztviselők befektetési döntéseinek meghozatalában. A Nemzetközi Valutaalap és az Európai Központi Bank (Caldara és Iacoviello, 2018) is a gazdasági kilátásokat fenyegető tényezőként emelte ki. A beruházások megtérülése nagymértékben szenved az ország politikai változásai vagy instabilitása miatt. Ezek a bizonytalanságok a kormányok, a jogszabályok, a külpolitika vagy a nagyobb katonai hatalom változásaiból eredhetnek. A geopolitikai kockázatok hatása az időhorizont elnyújtásával növekszik. Carney (2016) a gazdasági és politikai bizonytalansággal együtt belefoglalta a geopolitikai kockázatot a 'bizonytalansági háromságba', és azzal érvelt, hogy a geopolitikai bizonytalanságnak súlyos gazdasági hatásai lehetnek.

Ha egy gazdaságot geopolitikai kockázat fenyeget, az nagymértékben szétaprózza és instabillá teszi, ami miatt a vállalkozások is ingadozásokat mutatnak. Általános elvként kijelentve, ha egy ország a növekedés felfelé ívelő pályáján halad és jövője ígéretes, alapvetően kiszámítható, a befektetők szívesen fognak befektetni a gazdaságába. Az olyan váratlan események azonban, mint a háborúk, a katonai támadások, a politikai rezsim instabilitása stb., növelik a befektetésekhez kapcsolódó kockázatokat, és a befektetők óvakodnak befektetni olyan gazdaságokba, ahol ilyen jellegű kockázatok uralkodnak. A széleskörű globalizáció és a piacok összekapcsolódásának fokozódása miatt a geopolitikai kockázat - mint potenciális kockázat - a pénzügyi piacokra nézve minden eddiginél fontosabbá vált.

Az elmúlt három évtizedben a világban jelentősen megnőtt azoknak a szuverén szerep- lőknek a száma, akiknek döntései pozitív vagy negatív hatással lehetnek a világgazdaságra. Mindezeket az új szereplőket együttesen feltörekvő gazdaságoknak tekintik. A feltörekvő piacgazdaságok fontos helyet foglalnak el, mivel a globális gazdaság növekedésének fö mozgatórugói, és egyben gazdasági, pénzügyi lehetőséget is jelentenek a vállalkozások és a befektetők számára. A feltörekvő piacok a későbbiekben homályos rést jelentettek a befektetőknek. Mára azonban ezeket a globális befektetők a jövőbeli befektetések potenciális központjának tekintik. Ezek a gyorsan növekvő országok kritikus szerepet játszanak a globális gazdasági rendszerben. A globális gazdasági növekedés csaknem fele a feltörekvő piacokon zajlik. Azt mondják, hogy ha a befektetők diverzifikálják portfólióikat azáltal, hogy e gazdaságok részvényeit hozzáadják saját portfólióikhoz, képesek lesznek maximalizálni hosszú távú hozamaikat és diverzifikálni a kockázatot is. Hasonlóképpen, nem lehet figyelmen kívül hagyni az amerikai gazdaság jelentőségét sem a világban. Az Egyesült Államok a világ legnagyobb gazdasága, a világ GDP-jének csaknem negyedét teszi ki. A világ országainak majdnem egyötöde számára ez a legjelentősebb exportcélpont. Az Egyesült Államokban bekövetkező politikai változások nagyban befolyásolják a befektetők véleményét és a globális finanszírozási feltételeket. Tekintettel arra, hogy az amerikai gazdaság domináns szerepet tölt be a globális mintában, az amerikai politikai és gazdasági környezetben tapasztalható bármilyen bizonytalanság a feltörekvő gazdaságok volatilitásához vezethet. A politikai döntéshozók és a tudományos szakemberek egyaránt határozottan amellett érvelnek, hogy az Egyesült Államok gazdaságpolitikai bizonytalansága (EPU) erős átgyürűző hatással van a feltörekvő piacokra, mivel e gazdaságok és pénzügyi piacaik között nagyobb az összekapcsolódás.

A legtöbb múltbeli, a bizonytalansági mérőszámokra hivatkozó szakirodalomban ezek 
a tanulmányok a saját ország bizonytalanságát összefüggésbe hozták a részvényhozamokkal. A szakirodalom azonban tartalmaz néhány kivételt, mint például Mensi et al. (2014, 2016), Balcilar et al. (2015) stb. Ezek a tanulmányok a hagyományos középérték-alapú vektor-autoregressziós (VAR)modelleket vagy keresztkorrelációs függvényeket, kvantilis regressziókat, vagy kvantilis ok-okozati összefüggést alkalmazták az Egyesült Államok bizonytalanságai és a feltörekvő tőzsdék közötti kapcsolat vizsgálatára. A VAR és a kvantilis regressziók jelentéktelen eredményeket mutattak (lásd például Sum, 2012a,b) és a kvantilis ok-okozati összefüggéseket, amelyek az Egyesült Államok bizonytalanságából a fejlődő országok pénzügyi piacaira gyakorolt erős átgyürüző hatásokra utalnak (lásd például a Balcilar et al., 2015). Ezt követően az egyik kivétel Chulia et al. (2017) tanulmánya, aki az amerikai gazdaságpolitikai bizonytalanságnak a világ feltörekvő és fejlett piacainak részvényhozamaira gyakorolt hatását vizsgálta nemparametrikus kvantilis vektorautoregresszív megközelítéssel. A tanulmány bizonyítékot talált arra, hogy az amerikai politikai bizonytalanság jelentősen negatívan hat a feltörekvő pénzügyi piacok részvényhozamaira, különösen pénzügyi nehézségek idején, és bizonyította az amerikai gazdaságpolitikai bizonytalanságnak a feltörekvő és fejlett piacok részvényhozamaira gyakorolt átgyürüző hatását. Egy másik tanulmányt Balcilar et al. (2018) készített a geopolitikai kockázatnak a BRICS-gazdaságok tőzsdei dinamikájára gyakorolt hatásának kvantilis megközelítésben nemparaméteres ok-okozati összefüggést alkalmazva történő értékeléséről, és megállapította, hogy a BRICS-tőzsde nem egységesen reagált a geopolitikai kockázatra. Ez a tanulmány azonban jelentős mértékben hozzájárul a pénzügyi szakirodalomhoz, mivel dokumentálja a geopolitikai kockázat és a tőzsdei hozamok közötti ok-okozati összefüggést, de nem tartalmaz- za a kérdéses változókra gyakorolt hatás jeleire és tartósságára vonatkozó információkat, ami a kvantilis ok-okozati összefüggés megközelítésének egyik fö hátránya. E tanulmányok eredményeit vizsgálva felmerül a kérdés, hogy ha az USA gazdaságpolitikájának bizonytalansága és saját országának geopolitikai kockázata volatilitást okozhat a pénzügyi piacokon, van-e kapcsolat e két mérőszám között? A kapcsolatnak ezt az oldalát két okból is fontos feltárni. Először is, a szakirodalom bizonyította, hogy az USA gazdaságpolitikai bizonytalansága fertőző hatással van a feltörekvő gazdaságok tőzsdéire, másodszor pedig a feltörekvő gazdaságok tőzsdéinek volatilitása a gazdaság geopolitikai kockázataiból is eredhet.

$\mathrm{Az}$ országok gazdaságpolitikájában bekövetkezett strukturális változások mindig is komoly aggodalomra adtak okot a döntéshozók és a közgazdászok számára. Ennek az az oka, hogy az egyik ország gazdasági és pénzügyi rendszerének zavarai könnyen átterjedhetnek más országokra. Sőt, ez a hatás nagyobb horderejü is lehet, ha a világ a vezető gazdaságaiból ered, (Forbes, Chinn, 2004; Sum, 2012). Az ilyen átterjedő hatás egyik példája az USAban tapasztalható pénzügyi visszaesés, amely a 2007-2008-as globális pénzügyi válság néven ismert. A pénzügyi válság ugyan az USAból indult, negatív hatásait azonban a világ különböző gazdaságai is tapasztalták (Dakhlaoui, Aloui, 2014). A válság összetettsége az amerikai lakáspiacból indult ki, amely azután az Egyesült Âllamok és a világ többi részének pénzügyi piacát, különösen a feltörekvő és a határ menti gazdaságokat érintette (Bianconi et al., 2013).

Az említett tanulmányok hátterét felhasználva a jelen tanulmány célja, hogy megvizsgálja az Egyesült Államok politikai bizonytalanságának hatását Brazília, Oroszország, India, Kína és Dél-Afrika (BRICS) feltörekvő gazdaságainak geopolitikai kockázatára. A tanulmány eredményei hasznosak lehetnek 
a befektetők és a pénzügyi piac szereplői számára a befektetési döntések meghozatalában. Ez a törvényalkotóknak és a döntéshozóknak is hasznos lesz olyan politikák kidolgozásában, amelyek gazdaságukat elszigetelhetik a külpolitikai kockázatoktól.

A Quantile on Quantile Approach (a továbbiakban: QQ-megközelítés) módszert választottuk az említett változók kapcsolatainak vizsgálatára. Ezt a szemléletet a szóban forgó változók aszimmetrikus jellegének figyelembevételével választották. A QQ-megközelítés segít abban, hogy átfogóbb magyarázatot kapjunk a változók közötti kapcsolatra azáltal, hogy megvizsgáljuk mind a függő, mind a független változók eloszlási végét. A QQmegközelítés alkalmazásával modellezni tudjuk a GPR kvantilis értékét (és annak különböző gyakoriságait) az amerikai EPU kvantilis függvényében, hogy az e változók közötti kapcsolat eloszlásuk egyes pontjain változhasson, és teljes képet kapjunk a függőségről. Továbbá a változók közötti nem lineáris és aszimmetrikus kapcsolat feltételezése miatt a QQmegközelítés a legmegfelelőbb módszer ehhez a tanulmányhoz. Legjobb tudomásunk szerint ez az első olyan tanulmány, amely a QQmegközelítést használja arra, hogy tanulmányozza az amerikai politikai bizonytalanságnak a feltörekvő piacok geopolitikai bizonytalanságára való hatását.

A cikk felépítése a továbbiakban: a következő rész röviden ismerteti az adatokat és a módszertant, majd az empirikus eredményeket tárgyalja, és a végén a politikai következményekkel járó következtetéseket mutatja be.

\section{ADATOK ÉS MÓDSZERTAN}

A bizonytalanság eredendően egy belső változó. Ezért a megfelelő mérőszám meghatározása nem egyszerủ feladat. A bizonytalanság és más változók közötti kapcsolat számszerűsíté- séhez a múltbeli tanulmányok két mérőszámot használtak, nevezetesen a híralapú megközelítést vagy pedig a becsült strukturális VARmodellek hiba kifejezéseiben a sztochasztikus volatilitást alkalmazva a bizonytalanság kiszámításához. A Baker és szerzötársai (2016) a gazdaságpolitikai bizonytalanságra, valamint Caldara és Iacoviello (2018) a geopolitikai kockázatra javasolt híralapú megközelítés azonban népszerủbbnek tủnik, mint az utóbbi (a becsült strukturális VAR-modellek hiba kifejezéseiben a sztochasztikus volatilitás). Számos makrogazdasági és pénzügyi szakirodalmi tanulmányban alkalmazták a híralapú megközelítést (Raza és szerzőtársai, 2018; Chulia és szerzőtársai, 2017; Balcilar és szerzőtársai, 2018 stb.).

Ez a tanulmány ugyanezt a megközelítést alkalmazza, és híralapú bizonytalansági mérőszámokat használ az amerikai gazdaságpolitikai bizonytalanság és a BRICS-gazdaságok geopolitikai kockázata közötti kapcsolat becslésére. A gazdaságpolitikai bizonytalanság (EPU) és a geopolitikai kockázat (GPR) mérőszámaira vonatkozó adatok a szakpolitikai bizonytalansági (policyuncertainty) weboldalon érhetők el. ${ }^{2}$ Az 1985 januárjától 2018 februárjáig terjedő időszakra vonatkozó havi adatokat használtuk mindkét bizonytalansági mérőszámhoz, és mindkét mérőszámhoz kiszámítottuk a logaritmikus eredményeket.

A Baker és szerzőtársai által fejlesztett EPU-index (2016) az Access World New's NewsBank Service vezető újságainak archívumát használja. A következő mutató kiszámításához a hírcikkekben legalább egy kifejezést keresnek 3 adott kifejezésből, beleértve a gazdaság vagy gazdasági, a bizonytalan vagy bizonytalanság, a Federal Reserve, a deficit, a Kongresszus, a törvényalkotás és a Fehér Ház kifejezéseket. A kifejezések előfordulási gyakoriságát ezután szabványosítják a mutató kialakítása céljából. Ugyanezzel a megközelítéssel, Caldara és Iacoviello, (2018) algoritmus segít- 
ségével végzett geopolitikai kockázatimutatószámítást, hogy kiszámítsa a geopolitikai kockázathoz kapcsolódó cikkek gyakoriságát 11, az USA-ban megjelenő vezető újságban. A keresés alapvetően hat szócsoportot azonosít, beleértve a geopolitikai-, katonai zavar, nukleáris feszültség, háborús vagy terrorista fenyegetés vagy kedvezőtlen geopolitikai eseményekhez vezető bizonytalanság, mint a terrorista támadások vagy a háború kezdete csoportokat. $\mathrm{Az}$ értékeket ezután a 2000 és 2009 közötti évtizedben átlagosan 100-as értékre normalizálják a mutató kialakítása céljából.

A Sim és Zhou által megalkotott QQ (Quantile on Quantile)-módszer (2015) a sztenderd kvantilis regressziós modell általános meghatározása, ahol egy változó kvantiliseinek a másik változó feltételes kvantiliseire gyakorolt hatásai becsülhetők meg. A QQ-módszer egy, az exogén változó függő változó kvantiliseire gyakorolt hatását ellenőrző, kvantilis regreszszió és az exogén változók adott kvantilisének a függő változóra gyakorolt helyi hatásának értékelésére használt, helyi lineáris regreszszió kombinációja. A következő tanulmány keretének kialakításához a QQ-módszert alkalmazták az Egyesült Államok gazdaságpolitikai bizonytalanságának kvantilisei által a feltörekvő gazdaságok geopolitikai kockázatának kvantiliseire gyakorolt hatásának vizsgálatára és értékelésére. Kiindulópontként a következő nemparaméteres kvantilis regressziót használjuk:

$G P R_{t}=\beta^{\theta}\left(E P U_{t}\right)+u_{t}^{\theta}$

\section{Ahol}

a $G P R_{t}$ egy adott feltörekvő gazdaság geopolitikai bizonytalansági mutatóját jelöli egy adott $t$ időszakban,

az $E P U_{t}$ az USA gazdaságpolitikai bizonytalanságának súlyozott mutatója egy adott $t$ időszakban,

a $\theta$ a feltörekvő piacgazdaságokban a geopo- litikai bizonytalanság feltételes eloszlásának $\theta$. kvantilise és

az $u_{t}^{\theta}$ egy kvantilis hiba kifejezés, melynek feltételes $\theta$. kvantilise nulla.

A $\beta^{\theta}$ ismeretlen paraméter, mivel nincs korábbi információnk az USA gazdaságpolitikai bizonytalansága és a feltörekvő piacgazdaságok geopolitikai bizonytalansága közötti kapcsolatról.

A kvantilis regresszió modellezi az Egyesült Államok gazdaságpolitikai bizonytalanságának hatását a feltörekvő piacok geopolitikai kockázatára, megengedve a gazdaságpolitikai bizonytalanság hatásának váltakozását a geopolitikai kockázat különböző értékei között. E módszer alkalmazásának előnye a rugalmasság, mivel nem dolgoztak ki hipotézist az egyesült államokbeli gazdaságpolitikai bizonytalanság és a feltörekvő gazdaságok geopolitikai kockázata közötti kapcsolat hivatalos formájára vonatkozóan. Ennek a módszernek azonban hátránya is van, mivel nem képes teljes egészében értékelni a függőségi struktúrát. Ezért a kvantilis regresszió nem veszi figyelembe azt a lehetőséget, hogy a gazdaságpolitikai sokkok jellege befolyásolhatja a gazdaságpolitikai bizonytalanság és a geopolitikai kockázat összekapcsolódásának módját is. A nagy politikai változások hatása például nagyobb hatással lehet a geopolitikai bizonytalanságra, mint a kisebb politikai változásoké. Ezen kívül igen valószínü, hogy a geopolitikai kockázat aszimmetrikusan reagál az Egyesült Államokban végbemenő pozitív és negatív politikai változásokra.

Ezért a feltörekvő gazdaságok geopolitikai kockázatának $\theta$. kvantilisére és a gazdaságpolitikai bizonytalanság egyesült államokbeli

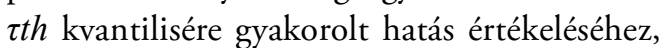
amelyet $E P U^{\tau}$-ként jelölünk, az 1. egyenletet adott $E P U^{\tau}$ viszonylatában elemezzük, helyi lineáris regresszióval. Mivel a $\beta^{\theta}$ egy ismeretlen tényező, az 1. egyenlet közelíthető egy elsőrendủ Taylor-soros kiterjesztéssel egy kvantilis 
$E P U^{\tau}$ körül, így az 1. egyenlet a következőképpen kerül transzformálásra:

$$
\beta^{\theta}\left(E P U_{t}\right) \nsim \beta^{\theta}\left(E P U^{\tau}\right)+\beta^{\theta^{\prime}}\left(E P U^{\tau}\right)\left(E P U_{t}-E P U^{\tau}\right)
$$

Itt a $\beta^{\theta^{\prime}}$ a $\beta^{\theta}\left(E P U_{t}\right)$ parciális deriváltja az EPU tekintetében, és marginális válasznak is tekinthető. A sztenderd lineáris regressziós modell meredekségi együtthatójaként értelmezik.

A 2. egyenlet fö elönye, hogy a $\beta^{\theta}\left(E P U^{\tau}\right)$ és a $\beta^{\theta^{\prime}}\left(E P U^{\tau}\right)$ a $\theta$ és a $\tau$ paraméterek függvénye, mivel a $\beta^{\theta}\left(E P U^{\tau}\right)$ és a $\beta^{\theta^{\prime}}\left(E P U^{\tau}\right)$ a $\theta$ függvényei és az $E P U^{\tau}$ az $\tau$ függvénye. Ezért, a $\beta^{\theta}\left(E P U^{\tau}\right)$ és a $\beta^{\theta^{\prime}}\left(E P U^{\tau}\right)$ átnevezhető $\beta_{0}(\theta, \tau)$ re, illetve, $\beta_{1}(\theta, \tau)$-re is. Tehát a 2 . egyenlet a következőképpen transzformálható:

$\beta^{\theta}\left(E P U_{t}\right) \approx \beta_{0}(\theta, \tau)+\beta_{1}(\theta, \tau)\left(E P U_{t}-E P U^{\tau}\right)$

$\mathrm{Az}$ 1. egyenlet a 3. egyenlet behelyettesítése után a következőképpen alakul:

$G P R_{t}=\beta_{0}(\theta, \tau)+\beta_{1}(\theta, \tau)\left(E P U_{t}-E P U^{\tau}\right)+u_{t}^{\theta}$

$(*)$

A 4. egyenlet $(*)$ része tulajdonképpen a feltörekvő gazdaságok geopolitikai kockázatának $\theta$ feltételes kvantilise, a feltörekvő piacok geopolitikai kockázatának $\theta$ kvantilise és az USA gazdaságpolitikai bizonytalanságának $\tau$ kvantilise közötti kapcsolatot jeleníti meg, mivel a $\beta_{1}$ és a $\beta_{0}$ a $\theta$ és a $\tau$ kettős függvénye, amely paraméterek a GPR $\theta$ és az EPU $\tau$. különböző kvantilisei között változhatnak. Továbbá a $Q Q R$-módszer azt feltételezi, hogy a szóban forgó változók kvantilisei között sosem áll fenn lineáris összefüggés. Így a 4. egyenlet az Egyesült Államok gazdaságpolitikai bizonytalansága és a feltörekvő piacgazdaságok geopolitikai kockázata közötti általános függőségi struktúrát értékeli a kvantilis eloszlásuk közötti függőség felhasználásával.

A 4. egyenlet empirikus becsléséhez az $E P U_{t}$ és az $E P U^{\tau}$-t becsült megfelelőikkel kell behelyettesíteni, azaz $\overparen{E P U_{t}}$ és $\overparen{E P U^{t}}$. Ahhoz, hogy megkapjuk a $b_{0}$ és $b_{1}$ paraméterek helyi lineáris regressziós becslését, amelyek a $\beta_{0}$ és $\beta_{1}$ empirikus becsült értékei, a következő minimalizálási függvényt kell megoldani:

$$
\begin{aligned}
& \min _{b_{0} b_{1}} \sum_{\mathrm{i}=1}^{\mathrm{n}} \rho_{\theta}\left[G P R_{t}-b_{0}-b_{1}\left(\widehat{E P U_{t}}-\widehat{E P U^{\tau}}\right)\right] \times \\
& \times K\left(\frac{\left.F_{n} \overparen{E P U_{t}}-\tau\right)}{h}\right)
\end{aligned}
$$

Itt a $\rho_{\theta}(u)$ a kvantilis veszteségfüggvény, amit $\rho_{\theta}(u)=u[\theta-I(u<0)]$-ként határozhatunk meg, ahol az $I$ a szokásos karakterisztikus függvény, a $K(\cdot)$ a kernel függvényt mutatja, a $h$ pedig a kernel sávszélesség paramétere. A következő tanulmány Gauss-féle kernelt használ. Hatékonysága és egyszerüsége miatt széles körben elterjedt a pénzügyi és gazdasági szakirodalomban. Arra használják, hogy az adatpontokat súlyozza a $E P U^{\tau}$ viszonylatában. A Gauss-kernel szimmetrikus eloszlása nulla körül van, és alacsony súlyokat rendel a távolabbi megfigyelésekhez. Az adott tanulmányhoz feltételezzük, hogy ezek a súlyok fordítottan viszonyulnak az $\overparen{E P U_{t}}$ empirikus eloszlásfüggvénye közötti távolsághoz és az $F_{n}\left(\overparen{E P U_{t}}\right)=\frac{1}{n} \sum_{\mathrm{k}}^{\mathrm{n}} I\left(\widehat{E P U_{k}}<\overparen{E P U_{t}}\right)$ egyenlettel írható le, a kvantilis $E P U^{\tau}$-nek megfelelő eloszlási függvény értékét pedig a $\tau$-vel jelöltük.

A sávszélesség kiválasztása kritikus feladat a nemparaméteres becslési technikák alkalmazása során. Meghatározza az adott adatpontot körülvevő értékek méretét, és így vezérli a kapott becslések szabályosságát. Míg a nagyobb sávszélesség nagyobb valószínűséggel eredményez torzítást a becslésekben, a kisebb sávszélesség nagyobb szórást eredményezhet. Ezért a sávszélességet úgy kell megválasztani, hogy fenn lehessen tartani a torzítás és a szórás közötti egyensúlyt. Sim és Zhou (2015) után egy $h=0,05$ sávszélesség-paramétert használunk a tanulmányban. 


\section{LEÍRÓ STATISZTIKA}

Az 1. táblázat a változók összefoglaló statisztikáit tartalmazza. Az (A) panel a USEPU eredményeit mutatja. A USEPU átlagértékének középértéke 0,0002, minimális értéke $-0,9188$, maximális értéke 0,252. A JB-statisztika 113,66-t mutat egy valószínüsített 0,000-es érték mellett, amely azt jelenti, hogy a USEPU logaritmus szerinti értéke nem normális.

Az 1. táblázat 2. panelje a BRIC-országok geopolitikai kockázati érték leíró statisztikáit mutatja be. A GPR-sorozat átlagértékei $-0,0012,-0,0006,-0,0002$ és 0,00004 Brazíliában, Oroszországban, Indiában és Kínában. Továbbá, bár Brazília kivétel, megfigyeltük, hogy a változók logaritmussorozata nem mutat normális eloszlást, és így a QQ-megközelítés alkalmazása felé terel a meredek esésnek megfelelően.

\section{EMPIRIKUS EREDMÉNYEK}

A BRIC-gazdaságok GPR $\theta$ th kvantilis értéke és az egyesült államokbeli EPU $\tau$ kvantilise kö- zötti összefüggésre vonatkozó QQ-adatokat az 1. ábra (A)-(D) panelek szemléltetik. A BRICgazdaságok geopolitikai kockázatának válasza az USA gazdaságpolitikai bizonytalanságára heterogén jellegű, ami azt jelenti, hogy az USA gazdaságpolitikai bizonytalansága nem befolyásolja egységesen a BRIC-gazdaságok geopolitikai kockázatát. $\mathrm{Az}(A)$ és (B) panel Kína és Oroszország eredményeit jeleníti meg. Ezeknek a gazdaságoknak van néhány közös vonásuk az egyes gazdaságok geopolitikai kockázata és az Egyesült Államok gazdaságpolitikai bizonytalansága tekintetében. Kína esetében negatív korreláció figyelhető meg az USA és Kína GPRkvantiliseinek szinte minden kombinációjában. Oroszország is nagyjából megerősítette az eredmények hasonló tendenciáját. Az egyesült államokbeli EPU és az oroszországi GPR kvantilis kombinációinak többségében a korreláció negatív. Ez azt jelenti, hogy az Egyesült Államokban a gazdaságpolitika elmozdulása nyilvánvalóan nem eredményez fokozott mozgást Kína és Oroszország geopolitikai kockázatában. Ezért az Egyesült Államok gazdaságpolitikai bizonytalansága nem tekinthető a geopolitikai kockázat hajtóerejének ezekben a gazdaságokban.

1. táblázat

\section{LOGARITMUSÉRTÉKEK LEíRÓ STATISZTIKÁJA}

\begin{tabular}{|l|c|c|c|c|c|c|c|c|}
\hline \multicolumn{1}{|c|}{ Ország } & N & Átlag & S. D. & Min. & Max. & Ferdítés & $\begin{array}{c}\text { Eloszlás- } \\
\text { görbe }\end{array}$ & JB \\
\hline (A) panel: USEPU logaritmus szerinti értékei & & & & \\
\hline USEPU & 397 & 0,0002 & 1,076 & $-0,9188$ & 0,252 & 0,679 & 5,241 & $113,66^{\star * *}$ \\
\hline (B) panel: BRIC GPR logaritmus szerinti értékei & & & & & \\
\hline Braźlia & 397 & $-0,0012$ & 0,782 & $-0,905$ & 0,276 & $-0,010$ & 3,085 & 0,128 \\
\hline Oroszország & 397 & $-0,0006$ & 1,019 & $-0,641$ & 0,214 & 0,386 & 4,489 & $46,585^{\star \star *}$ \\
\hline India & 397 & $-0,0002$ & 1,164 & $-0,641$ & 0,221 & 0,714 & 5,576 & $143,562^{\star * *}$ \\
\hline Kína & 397 & 0,0004 & 0,560 & $-0,485$ & 0,184 & 0,272 & 3,212 & $5,677^{\star *}$ \\
\hline
\end{tabular}

Megjegyzés: $A^{* * *}$ és ** csillag 1 százalékos, illetve 5 százalékos szinten jelentős.

Forrás: saját szerkesztés 


\section{KVANTILIS/KVANTILIS MEGKÖZELÍTÉS SZERINTI BECSLÉSEK}

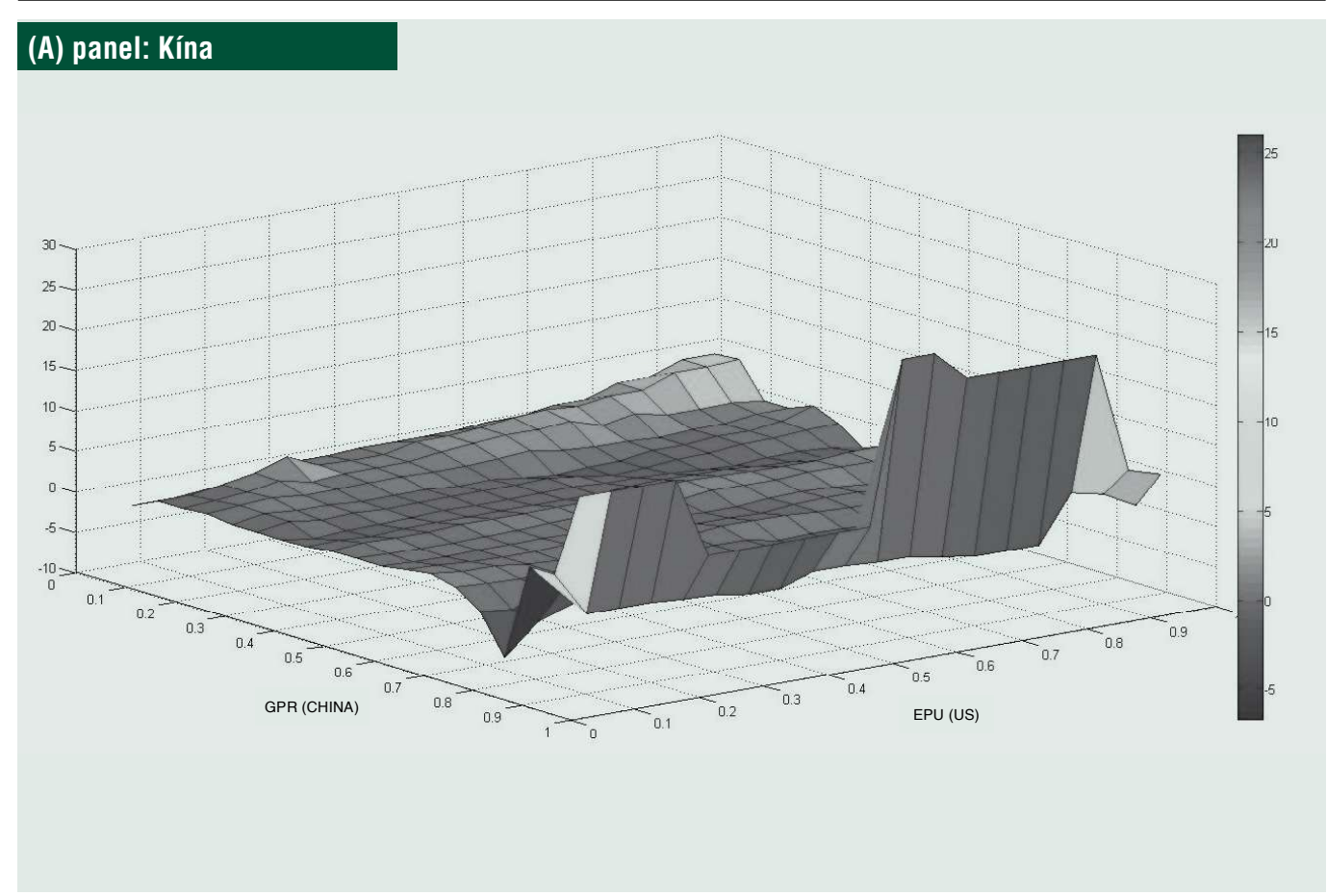

(B) panel: Oroszország

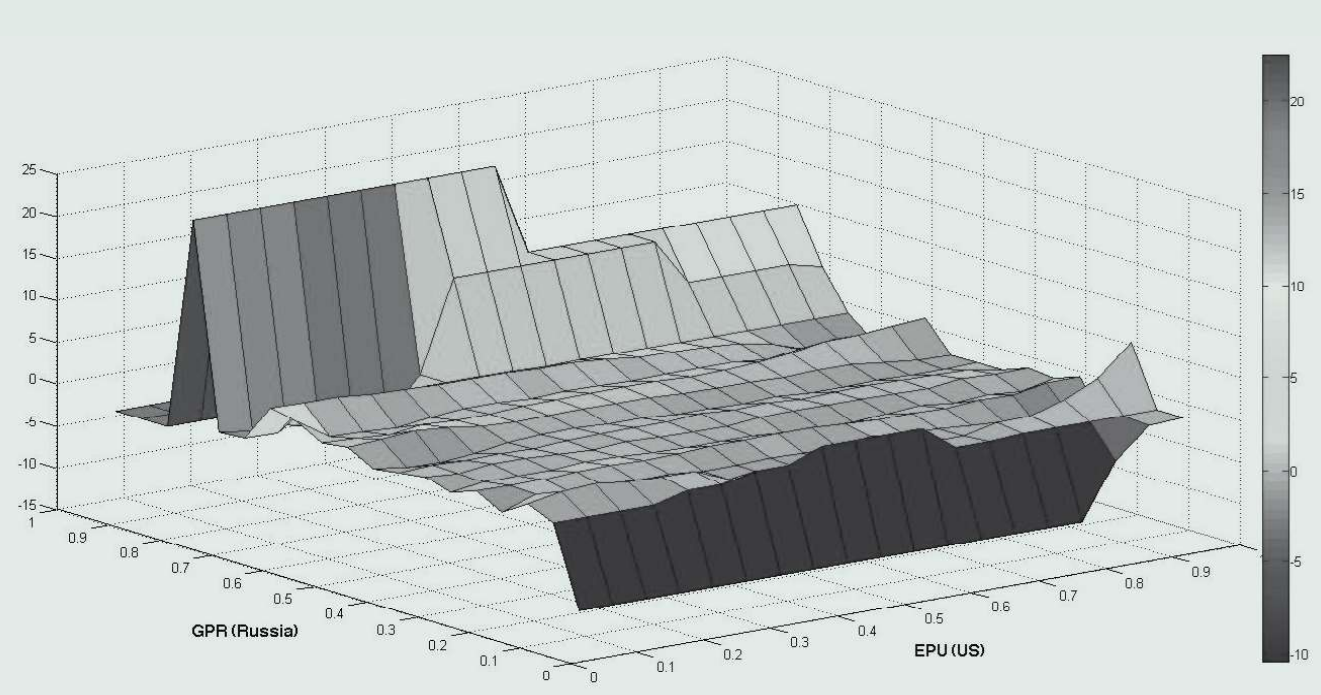




\section{KVANTILIS/KVANTILIS MEGKÖZELÍTÉS SZERINTI BECSLÉSEK}

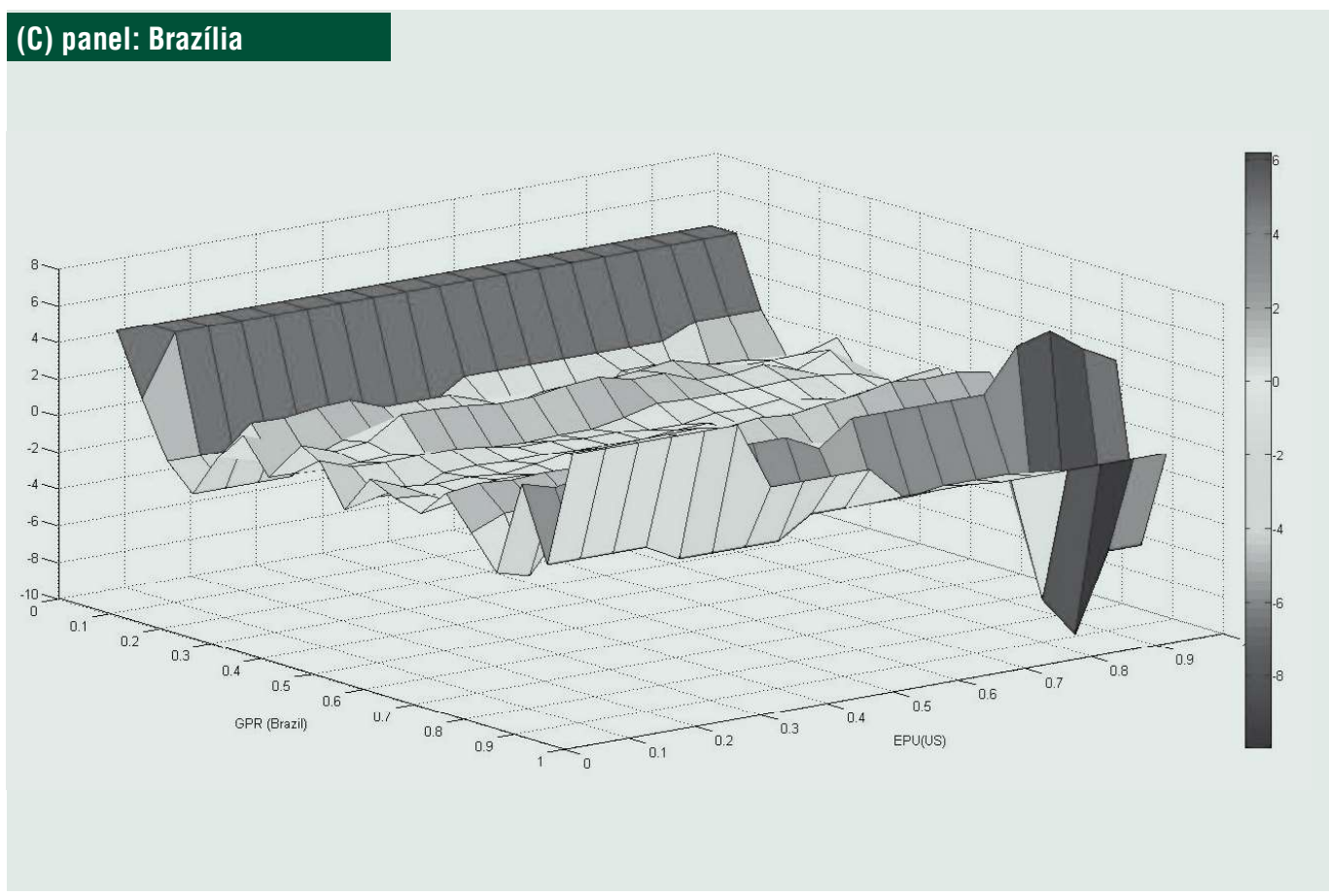

\section{(D) panel: India}

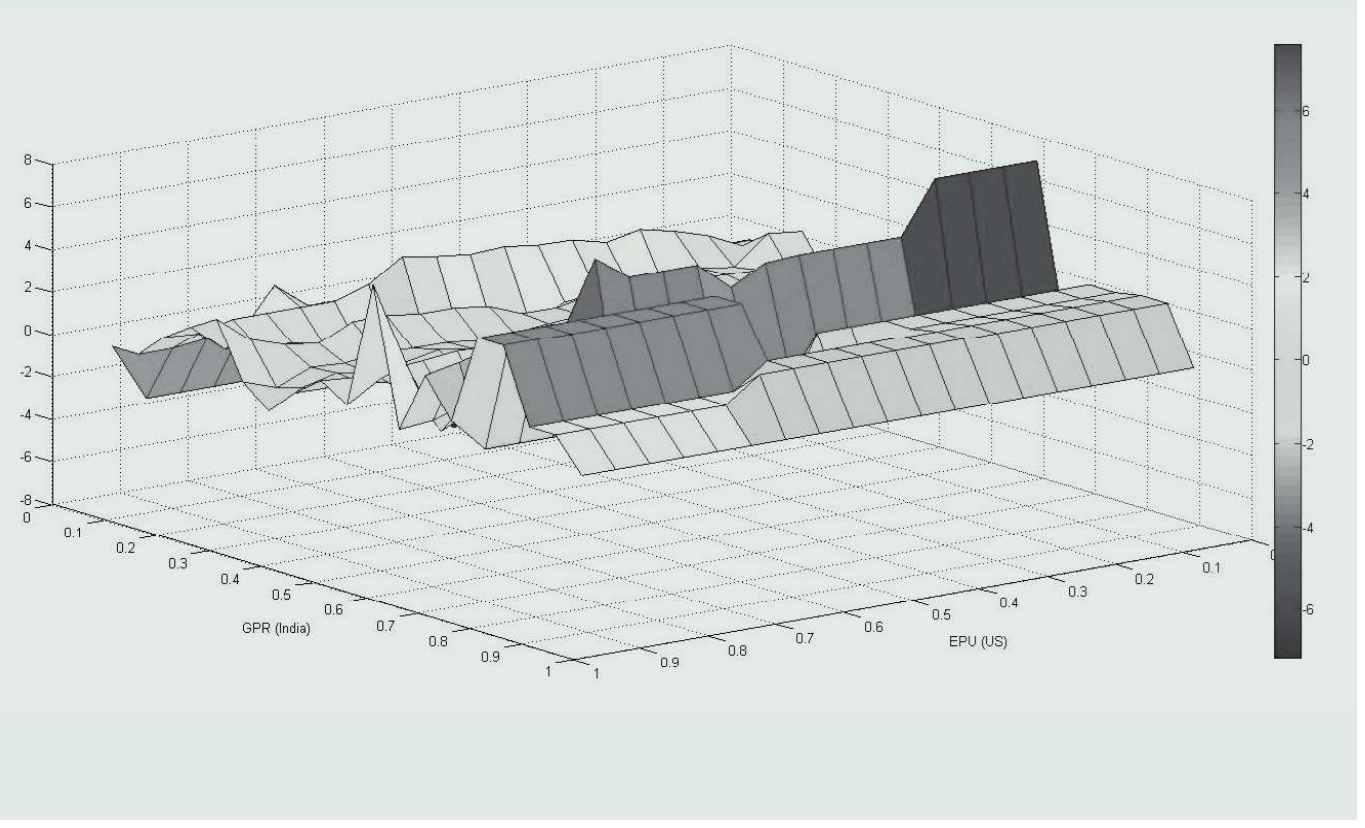


Brazília és India azonban meglehetősen ellentmondásos eredményeket mutatott. $\mathrm{Az} 1$. ábra $(C)$ és $(D)$ panelje e gazdaságok eredményeit képviseli. Az eredményekből megállapítottuk, hogy az Egyesült Államok gazdaságpolitikájának bizonytalansága viszonylag erőteljesebben hat Brazília és India geopolitikai kockázatára. Az egyesült államokbeli EPU, valamint Brazília és India GPR-je közötti kapcsolat a kvantilis kombinációk túlnyomó többségében pozitív. A politikai bizonytalanságok közötti pozitív kölcsönös függőség miatt az amerikai EPU geopolitikai bizonytalanságot idézhet elő a brazil és az indiai gazdaságban.

\section{KÖVETKEZTETÉSEK ÉS SZAKPOLITIKAI KÖVETKEZMÉNYEK}

A geopolitikai kockázat a beruházások és az üzleti döntések meghozatalának egyik fö meghatározója. A világ egyre növekvő geopolitikai bizonytalansága felerősítette az ehhez kapcsolódó kockázatok hatását. A geopolitikai kockázat nemcsak az általános gazdasági kilátások megzavarására képes, hanem a részvényhozamok volatilitásának előidézésére is. Hasonlóképpen nem szabad figyelmen kívül hagyni a gazdaságpolitikai bizonytalanság jelentőségét a globális gazdasági dinamikában. A globális pénzügyi válságot követően a gazdasági és pénzügyi szakirodalom nagy része a gazdasági bizonytalanság hatására összpontosított, azonban a múltbeli szakirodalom nagy részét a saját országra jellemző bizonytalanságnak a hazai részvényhozamokra gyakorolt hatásának mérésére fordították, hagyományos, átlagos regressziós modellek alkalmazásával. Tekintettel arra, hogy az Egyesült Államok gazdaságpolitikájának bizonytalansága erősen fertőző hatásokkal jár, azzal érvelünk, hogy fontos ellenőrizni az Egyesült Államok gazdaságpolitikájának bizonytalansága és a BRIC-gazdaságok geopolitikai kockáza- ta közötti kapcsolatot, mivel mind az Egyesült Államok gazdaságpolitikájának bizonytalansága, mind a geopolitikai kockázat a fellendülőben lévő gazdaságok tőzsdéi volatilitásának mozgatórugója. Nagyon valószínű, hogy mindkét változó összekapcsolódik, ezért ellenőrizni kell az ezen intézkedések közötti kapcsolatot. Ezen túlmenően, mivel a kockázati és bizonytalansági mérőszámok meredeken csökkennek, a hagyományos átlagos regressziós modellek, amelyek a változók normális eloszlását feltételezik, nem elegendőek, és hamis eredményekhez vezethetnek. A szakirodalomban van pár kivétel néhány nemparaméteres becslés alkalmazása tekintetében, mint például az ok-okozati öszszefüggés a kvantilis megközelítésben vagy a kvantilis vektoros autoregresszív megközelítés, miközben a hazai és globális bizonytalanság hazai tőzsdékre gyakorolt hatását vizsgálja. E tanulmányok egyike sem szerepel azonban olyan korábbi szakirodalomban, amely megkísérelte volna ellenőrizni az amerikai gazdaságpolitikai bizonytalanság és a geopolitikai kockázat közötti kapcsolatot.

A gazdaságpolitikai bizonytalanság és a geopolitikai kockázat közötti kapcsolat számos módon befolyásolhatja az eszközárakat. Mindenekelőtt, amikor egy globális pénzügyi sokk bizonytalanságot okoz a gazdaságban, az késlelteti a vállalatok és a befektetők döntéshozatali folyamatát. Másodszor, megemeli a termelési és finanszírozási költségeket azáltal, hogy negatívan hat mind a keresleti, mind a kínálati csatornákra, és következésképpen fokozza a beruházások megszüntetését és a gazdasági visszaesést. Harmadszor, növeli a pénzügyi piaci befektetésekhez kapcsolódó kockázatot.

Ezen elképzelés alapján az adott tanulmány a BRIC-gazdaságok geopolitikai kockázatának az amerikai gazdaságpolitikai bizonytalanságra adott válaszát nemparaméteres becslési technikával, azaz a Sim és Zhou által javasolt Quantile on Quantile megközelítéssel értékeli (2015). Megállapításaink szerint a 
négy BRIC-gazdaság közül Kína és Oroszország nagymértékben elszigetelődött az amerikai gazdaságpolitikai bizonytalanságtól, mivel az amerikai EPU és az egyes gazdaságok GPRkvantiliseinek legtöbb kombinációja negatív korrelációt mutatott. A brazil és indiai gazdaságok esetében az Egyesült Államok politikájának bizonytalansági sokkjai geopolitikai kockázatot idéztek elő ezekben a gazdaságokban, mivel a GPR és az amerikai EPU kvantilis kombinációinak többsége pozitív korrelációt mutatott.

Cikkünk megállapításai jelentősen hatnak a cégek, vállalkozások befektetőire és pénzügyi politikai döntéshozóira. Számos tényező okoz- hat heterogenitást a feltörekvő piacok amerikai gazdasági bizonytalanságra adott válaszaiban. Ezek a tényezők magukban foglalják a pénzügyi kockázatokat, a belföldi kereslet instabilitását, valamint a devizatartalékaikban lévő USA-dollárnak való kitettséget. Ezen kívül ezek a gazdaságok is ki vannak téve a „koszos pénz" gazdasági rendszerükbe történő kiés beáramlásának, ami megtörheti őket. Ezért határozottan ajánlott, hogy ezek a gazdaságok növeljék pénzügyi és gazdasági rendszereik erejét. Erős pénzügyi és gazdasági rendszerüknek köszönhetően ezek a gazdaságok képesek lesznek csökkenteni az Egyesült Államok EPU átviteli kockázatát.

\section{JeGYZET}

1 A BRIC rövidítést Jim O'Neill, a Goldman Sachs (befektetési bank és pénzügyi szolgáltató) vezető közgazdásza alkotta 2001-ben, Brazília, Oroszország, India és Kína kezdőbetűiből áll össze a mo- zaikszó, amely 2010-ben - Dél-Afrikával kiegészülve - BRICS-re módosult.

2 http://www.policyuncertainty.com.

\section{IRODALOM}

Arif, I., IQbal, A., Ali, S. F., SohaIL, A. (2017). International Stock Market Diversification among Brics-P: A Cointegration Analysis. Journal of Management Sciences, 4(2), pp. 269-285

Baker, S. R., Bloom, N., Davis, S. J. (2015). Measuring economic policy uncertainty. National Bureau of Economic Research Working Paper, No. w21633

Balcilar, M., Gupta, R., Kim, W-J., Kyei, C. (2015). The Role of Domestic and Global Economic Policy Uncertainties in Predicting Stock Returns and their Volatility in Hong Kong, Malaysia, and South Korea: Evidence from a Nonparametric Causality-in-Quantiles Approach. Department of
Economics, University of Pretoria, Working Paper, No. 201586

Balcilar, M., Bonato, M., Demirer, R., Gupta, R. (2018). Geopolitical Risks and Stock Market Dynamics of the BRICS. Economic Systems, https://doi.org/10.1016/j.ecosys.2017.05.008

Caldara, D., Iacoviello, M. (2018). Measuring Geopolitical Risk. Federal Reserve Board International Finance Discussion Paper, No. 1222, http://dx.doi.org/10.17016/IFDP.2018.1222

Carney, M. (2016). Uncertainty, the economy and policy. Bank of England, https://www.bis.org/review/r160704c.pdf 
Chuliá, H., Gupta, R., Uribe, J. M., Wohar, M. E. (2017). Impact of US uncertainties on emerging and mature markets: Evidence from a quantile-vector autoregressive approach. Journal of International Financial Markets, Institutions and Money, 48, pp. 178-191

Mensi, W., Hammoudeh, S., Reboredo, J. C., Nguyen, D. K. (2014). Do global factors impact BRICS stock markets? A quantile regression approach. Emerging Markets Review, 19, pp. 1-17

Mensi, W., Hammoudeh, S., Yoon, S-M., Nguyen, D. K. (2016). Asymmetric Linkages between BRICS Stock Returns and Country Risk Ratings: Evidence from Dynamic Panel Threshold Models. Review of International Economics, 24(1), pp. 1-19
Raza, S. A., Zaighum, I., Shah, N. (2018). Economic policy uncertainty, equity premium and dependence between their quantiles: Evidence from quantile-on-quantile approach. Physica A: Statistical Mechanics and its Applications, 492, pp. 2079-2091

Sim, N., Zhou, H. (2015). Oil prices, US stock return, and the dependence between their quantiles. Journal of Banking \& Finance, 55, pp. 1-8

Sum, V. (2012a). The Reaction of Stock Markets in the BRIC Countries to Economic Policy Uncertainty in the United States. SSRN Paper, No. 2094697

Sum, V. (2012b). How Do Stock Markets in China and Japan Respond to Economic Policy Uncertainty in the United States? SSRN Paper, No. 2092346 